\title{
Adoption of Mobile Banking in Jordan: Exploring Demographic Differences on Customers' Perceptions
}

\author{
Ali Abdallah Alalwan ${ }^{1}$, Nripendra P. Rana ${ }^{2}$, Yogesh K. Dwivedi ${ }^{2}$, Banita Lal ${ }^{3}$, \\ Michael D. Williams ${ }^{2}$ \\ ${ }^{1}$ Amman College of Banking and Financial Sciences, Al-Balqa' Applied University, Amman, \\ Jordan P.O: Amman 1705 Jordan \\ \{alwan.a.a.ali@gmail.com\} \\ ${ }^{2}$ School of Management, Swansea University, Swansea, SA2 8PP, United Kingdom \\ \{nrananp@gmail.com, ykdwivedi@gmail.com,m.d.williams@swansea.ac.uk\} \\ ${ }^{3}$ Nottingham Business School, Nottingham Trent University, NG1 4BU, United Kingdom \\ \{banita.lal@ntu.ac.uk\}
}

\begin{abstract}
This study aims to explore whether Jordanian customers' perceptions on intention and adoption of Mobile banking (MB) services varies according to their demographic characteristics. As per the prior literature, five demographic factors, namely age, gender, income, education and customer's experience with computer and Internet have been considered in the current study. The required data were collected from the field survey questionnaires administered to a convenience sample of Jordanian banking customers. The major statistical results (mean and standard deviation) demonstrate that the customers' perceptions on intention and adoption of MB are likely to vary due to customers' demographic differences. According to the current study's findings, it was also noticed that despite the fact that the most of the sample respondents express a high intention to adopt $\mathrm{MB}$, the adoption rate for the majority of $\mathrm{MB}$ services was low.
\end{abstract}

Keywords: Mobile banking, Customer, Jordan, Demographic differences, Adoption, Behavioral intention

\section{Introduction}

Mobile banking (MB) is identified as the "use of mobile terminals such as cell phones and personal digital assistants to access banking networks via the wireless application protocol (WAP)" [44, p. 760]. Such innovative banking channel has been progressively implemented over the banking context worldwide to launch customers a wide range of the higher quality banking services (i.e. balance enquiries, fund transfers, payment of bills) without any time or place restrictions [42].

In Jordan, banks seem to be more motivated to adopt MB as an essential banking channel to increase the geographical coverage, customer's satisfaction and loyalty as 
well as to minimise the operational and labour costs related to traditional branches [4, 26, 32, 33, 42]. Further, the mobile and telecommunication area is growing phenomenally; where there are four mobile services providers along with up to 8.984 million of mobile subscriptions [37]. Practically, out of 26 banks working in Jordan, 15 banks have Launched MB services [26].

However, banks worldwide express their concerns regarding the lower adoption rates of MB services by customers. By the same token, Jordanian banking customers seem to be not fully motivated to adopt MB [5]. According to recent study by Alafeef et al. (2011), 6\% of the total Jordanian banking customers have actually used MB services. Alafeef et al. [3] also mentioned that $31 \%$ of banking customers are not aware of the existence of MB services introduced by their banks.

Accordingly, it could be concluded that the main challenge pertaining to successful implementation of $\mathrm{MB}$ is conceiving bank clients to move from using human encounter to fully adopt MB [44]. Thus, there is always a necessity to identify the main factors that could hinder or enhance customers' intention and adoption of MB. However, MB related issues have been rarely examined in Jordan. Furthermore, banks need to have more information regarding customers' perception on intention to use and adoption of MB that could differ as per the demographic differences. This, in turn, will help these banks to conduct a useful market segmentation strategy that could accelerate the customers' intention and adoption of such technology $[14,16,31$, 34]. Accordingly, this study aims to conduct an empirical examination to discover if there are considerable variations in the Jordanian customer's perception on the intention and adoption of MB.

\section{Literature Review}

Theoretically, many studies have endeavored to interpret the most important factors that could hinder or foster customer intention and acceptance of Mobile banking. For instance, Püschel et al. [30] claimed that Brazilian customers' attitudes towards Mobile banking were significantly affected by relative advantage, followed by compatibility; ultimately enriching the customers' intention to adopt Mobile banking. Brown et al. [7] also found that banking customers are more enthused to adopt Mobile banking by relative advantage, trialability, and consumer banking needs. Perceived benefits and governmental regulations have been confirmed as the key positive enablers of customer attitudes towards Mobile banking in Indonesia [29]. In line with this, customers were found to be more motivated to use Mobile banking if they recognised Mobile banking as being useful in their daily life, compatible with their habits and other technologies, and less expensive [18, 42]. By the same token, customer intention to adopt Mobile banking was significantly determined by the role of perceived usefulness, monetary cost, self-efficacy and perceived ease of use [23]. Later, Zhou [43] empirically supported the considerable role of a bank's reputation, information quality, self-efficacy, service quality, and system quality in shaping the customers' initial trust in Mobile banking. More recently, Hanafizadeh et al. [18] all 
supported the crucial role of perceived usefulness and ease of use in motivating customers to adopt Mobile banking.

With regard to the role of demographic factors, Laukkanen and Pasanen [22] indicated that customers' adoption of Mobile banking was exclusively predicted by the customers' age and gender, but was not predicted by education level, career, family size and income. Riquelme and Rios [35] revealed that the males' intention to adopt Mobile banking was strongly affected by the role of perceived usefulness, while females paid particular attention to aspects related to ease of use. Chiu et al. [9] indicated that there were no statistical differences in the role of these factors on customers' intention. Laukkanen [21] also discussed that regardless of age differences, customers seem to be more reluctant to adopt Mobile banking due to the negative role of value and usage barriers, while mature customers were observed to be more concerned about barriers pertaining to risk, image, and traditional barriers.

Nevertheless, there is a dearth of literature addressing customer intention and usage of Mobile banking by Jordanian banking customers [5, 19]. Both Khraim et al. [19] and Awwad and Ghadi [5] have found that Mobile banking characteristics trialability, complexity, compatibility, relative advantages, and risk - are the key predictors of Jordanian customer intention and adoption of Mobile banking. Yet, there is still a need to clarify and empirically examine the important role of the customers' characteristics (i.e. age, gender, income, education, and technology) in shaping the Jordanian customers' perception on intention to use MB and adoption of such emerging systems. Thus, in order to fill this gap, current study intends to empirically test and explore whether Jordanian customers' perceptions on intention and use of $M B$ could vary according to their demographic characteristics: age, gender, income, education, customers' experience with computer and Internet.

\section{Theoretical Basis}

The impact of demographic factors has received a great deal of attention from information systems studies, which assert that variations in customers' reactions to and perceptions of technology could be attributed to the variation in the customers' demographic characteristics [11, 28]. Therefore, this study examines how the demographic factors (such as age, gender, income, education, and customers' experience with computer and Internet) could reflect differences in the Jordanian customers' perception on intention to use and actual adoption of Mobile banking services. These five factors have been widely studied and examined over the online banking area $[12,24,25]$. Further justification and discussion regarding each of these factors are provided in the following subsections.

\subsection{Age}

Theoretically, age has been debated either as an independent variable or as a factor that could lead a variation on the persons' perception toward a certain kind of 
individual or collective behaviour and actions [17]. Likewise, prior studies over the information system area have paid a particular interest for the important role of age in shaping the individual perception on the aspects related to technology (i.e. usefulness, ease of use, behavioural intention and actual usage of technology [39, 40, 41]. According to Venkatesh et al. [38], actual adopters of computer were found largely to be within the age range of 15 to 35 years. In the self-service technology (SST) context, Dabholkar et al. [11] observed that customers are more likely to be varying on their intention towards and usage of SST according to their age. Therefore, it could be expected that the Jordanian banking customers' perceptions on intention and adoption of $M B$ would differ according to their age groups.

\subsection{Gender}

According to Morgan [27], gender could be debated either as a descriptive variable or as an explanatory variable. Over the information system (IS) area, a number of authors $[39,40,41]$ have examined the role of gender in moderating or directly predicting the individual' perception, intention and behaviour toward technology. In keeping with Venkatesh et al. [38], the usage of computer is more likely to be in the higher level among males than females. Differently, some IS researchers [12, 38, 40, 41] have indicated that men are more likely to accept a new technology based on the benefits and advantages perceived; while women usually pay more attention to aspects related to complexity, facilitated resources, and assurance. Therefore, it could be expected that the Jordanian banking customers' perceptions on intention and adoption of MB would differ according to their gender.

\subsection{Education}

In the line with Burgess's [8] proposition, individuals who enjoy an adequate education level are more likely to have a positive perception and ability to conduct a set of complicated actions. Therefore, it has been largely claimed that the welleducated people are more likely to have a positive reaction and perception toward new innovations, thereby; they are more likely to adopt a new technology in comparison with those who are at the less educational level $[8,36]$. This thought has been also approved by number of IS studies [2, 28, 38]. For example, Al-Somali et al. [2] empirically proved that Saudi banking customers, who have an adequate level of education, are more likely to have positive attitudes toward Internet banking. Therefore, it could be expected that the Jordanian banking customers' perceptions on intention and adoption of MB would differ according to their education level.

\subsection{Income}

Instead of the employee context where the cost could be restricted in terms of time and effort, customers are more likely to be sensitive to the financial issues that could form their perception toward using the technology [24]. Generally speaking, 
customers with higher income are more likely to be able carry the financial cost associated with using a new technology [36]. Indeed, using MB services could require customers to pay a cost for using such services in addition to the other cost of having a smart phone, Internet access, and using specified applications [35]. From this perspective, banking customers' perception toward such novel technology could be different according to the customers' income level. This proposition was confirmed by Meuter et al. [25] who empirically approved income level as a key determinant of both customer readiness and customer experiment of different kinds of self-service technologies. Al-Ashban and Burney [1] also empirically approved income level as a considerable positive predictor of the customers' acceptance of Telebanking in Saudi Arabia. Likewise, according to Kolodinsky et al. [20], the adoption rate of Internet banking channels was observed to be in the higher level among customers who have a higher income level instead of lower income customers. Therefore, it could be expected that the Jordanian banking customers' perceptions on intention and adoption of $M B$ would differ according to their income level.

\subsection{Experience}

Given the particular nature of $\mathrm{MB}$ as a self-service banking channel requiring customers to produce the financial services without any assistance from banking staff, the adequate levels of experience and skills with technology could be the important prerequisites to successfully apply this technology (Meuter et al., 2005). Hence, customer experience has been identified by a number of studies as a crucial determinant of customer perception and behaviour towards SST [24, 25]. With reference to Meuter et al. [25], prior experience strongly influences the customer's decision to try a self-service technology, either directly or indirectly, through the mediating impact of customer readiness. Further, customer experience was found to be one of the most influential factors predicting customer propensity toward mobile ticketing in a transportation context [24]. Based on empirical results established by Curran et al. [10] and Chiu et al. [9] customer familiarity in dealing with self-service technology has a significant and positive impact on customers' intention and orientation toward this technology. Therefore, it could be expected that the Jordanian banking customers' perceptions on the intention and adoption of MB would differ according to customer's experience with computer and Internet.

\section{Research Methodology}

Either in information system area or the MB context, it has been highly noticed that the field survey is one of the most prevalent and commonly adopted methods for testing an individual's intention and behaviour towards such an emerging system [13, 15]. Further, this study was conducted with the aim to test and explain the Jordanian banking customers' perception on intention and adoption of Mobile banking. Therefore, the field survey was found to be the most suitable and cost-effective research method allowing access to a large number of Jordanian banking customers in different places within a reasonable time [6]. This, in turn, led to observe that the self- 
administered questionnaire was a suitable data collection method to obtain the required data from Jordanian banking customers.

As mentioned before, the self-administered questionnaire was selected to derive responses from Jordanian banking customers regarding their perception of the aspects related to behavioural intention and use of Mobile banking. The seven-point Likert scale was used to measure the behavioural intention items with anchors ranging from ' 1 - strongly agree' to ' 7 - strongly disagree'. A set of six common financial services was adopted to measure the adoption of Mobile banking. These services have been widely adopted by relevant studies that have examined customers' use or adoption of Internet banking, Mobile banking, and Telebanking [23, 30, 44]. The seven-point time scale was adopted to measure the use behaviour toward these services with anchors including: 'never', 'once a year', 'several times a year', 'once a month', 'several times a month', 'several times a week', 'several times a day' [41]. Furthermore, six close-ended questions were used for demographic variables such as age, gender, income, education level, Internet experience, and computer experience.

\section{Results}

\subsection{Descriptive Analysis of Usage Behavior}

We provide a statistical description regarding the usage patterns of the six Mobile banking services. Balance enquiries and downloading bank statements seem to be the most frequently used Mobile banking services that are applied by the respondents. Indeed, of the 343 valid responses, 105 (30.6\%) used Mobile banking several times per month to look at their bank balance or to download the balance on their bank statement. Yet, balance enquiries and downloading of bank statements via mobile banking have never been used by $85(24.8 \%)$ of the respondents. In summary, the average mean usage of balance enquiries and downloading bank statements performed by using Mobile banking was 3.65 and the standard deviation was 1.83 .

Paying bills was the next widely used Mobile banking service as 110 respondents (i.e. $32.1 \%$ ) have used Mobile banking to pay bills once a month while, $130(37.9 \%)$ valid responses mentioned that they have never used Mobile banking to pay bills. In addition to these, the usage mean of paying bills performed by Mobile banking was 2.77. The third Mobile banking service used by respondents was funds transfer. Even though $145(42.2 \%)$ of the respondents mentioned that they have never transferred funds through Mobile banking, $118(34.4 \%)[60+58]$ of the respondents indicated that they had utilised Mobile banking for funds transfer about once a month or several times a year. The usage mean of this service was 2.41 and its standard deviation was 1.52. A total of 79 [44 +35$](23 \%)$ respondents used Mobile banking to request a chequebook or bank certificates several times per year or once a year. Yet, many more respondents (i.e. 179, 52.1\%) have never used the Mobile-banking channel to receive the same services. The mean of using Mobile banking to obtain these services was 2.21 and the standard deviation was 1.52 . 
Of the few who have used mobile banking for payment of instalments of loans and mortgages, $51(14.8 \%)$ of the respondents have used Mobile banking for these services once per month. However, as seen in Table 1, the vast majority of respondents (i.e. 224, 65.3\%) reported that they have never applied for these services via Mobile banking. The mean of using mobile banking to conduct these services was too low (about 1.88) with the standard deviation of 1.35.

Moreover, 237 respondents (69\%) have never used these services. Only 94 [33+ $33+28](27.4 \%)$ used Mobile banking to perform these services once a year, several times per year, and once a month respectively. Moreover, these services had the lowest usage mean (i.e. 1.68) among the Mobile banking services and its standard deviation was 1.18 .

\subsection{Respondent's Demographic Characteristics and Customers' perception relating to Intention to Use and Adoption of Mobile banking}

Both mean and standard deviation (SD) are tested in the current study to see how the customers' perception regarding the issues related to behavioral intention and adoption of MB could be vary according to respondent's demographic characteristics. In the term of age difference, all age categories express a high intention to use MB. Yet, according to the average mean accounted for age group 25-30 and 31-40, younger generation seems slightly more interested in using MB in future. The actual adoption mean extracted for age categories indicted the lower adoption rates of $\mathrm{MB}$ services by Jordanian customers. However, the adoption rates of MB were noticed in their highest level for age group 25-30 followed by age group of 31-40.

As for gender difference, both male and female seem to be more willing to adopt MB due to the highest mean score accounted in this regard, yet; the mean accounted for male was higher than for female. On the other hand, the usage mean accounted for both male and female was low with value of 2.27 for male and another lower value for female (i.e. 2.012).

According to main statistical outcomes regarding the refection of educational level, as expected, the highest rate of behavioural intention was noticed regarding those respondents who have a $\mathrm{PhD}$ degree with mean value of 6.33 followed by those who have masters (5.39) and Bachelors (5.37) degrees. By the same token, the largest mean of the adoption behaviour was accounted for respondents who have a $\mathrm{PhD}$ with mean value of 2.28. Lower adoption means were also recorded for the all education groups.

In the term of computer experience, the largest mean value of behavioral intention (i.e. 5.62) was accounted for those respondents who have three years of experience or above with computer while the value of 4.25 , which is the lowest value was accounted for those who have less than three years of experience with computer. Similarly, the highest mean value of adoption (i.e. 2.26) was noticed in the case of respondents who have experience of three years and above.

As for Internet experience, the largest mean (i.e. 5.47) of behavioural intention was accounted by those respondents who have experience with Internet for three years and above. On the other hand, the lowest mean (i.e. 4.25) of behavioural intention was in 
the case of respondents with Internet experience less than one year. By the same token, the largest mean (i.e. 2.22) of adoption of MB services was in the case of Internet experience of three years or above whereas the lowest one (i.e. 1.92) in this regard was in the case of experience group of 1-2 years.

\section{Discussion}

Generally, the main results extracted in the current study were found to be in line with what has been discussed and approved by prior literature regarding the role of demographic factors on the perception toward technology. For instance, the age categories of 25-30 and 31-40 express a higher willingness toward using $\mathrm{MB}$ in comparison with older customers (i.e. 50-60 and those above 61). Even though the adoption rates of $\mathrm{MB}$ services are too low over all age groups, younger customers were observed as highly involved in using $\mathrm{MB}$ in comparison to older customers. Such issues could possibly return to the fact that older customers are more likely to not have the important skills and experience that enable them to properly use MB and most of them they do not have smart phones needed to use MB services. Younger customers seem to have more capability and confidence to interact with such sophisticated technology like Mobile banking. This could be regarded to the fact that younger customers have more interaction with technology and Mobile innovation and having an adequate level of technological savvy, awareness, skills, and knowledge, $[41,42]$.

As for gender, the findings indicated that there are slight differences between males and females in their perception toward intention and adoption. Nevertheless, it could be difficult in the current stage to argue that males are more interested and hence can heavily adopt MB services than females. This could be attributed to the fact that the influence of gender differences are more likely to vanish over the highly evolved communities where both males and females have equal opportunities to be educated, to work, and to get interacted with technologies. In parallel with these results, there are several studies $[11,12]$ that have empirically disapproved a variation between males and females in their intention and reaction toward technology.

In line with what has been expected regarding the role of education, highly educated respondents seem to be more motivated to use MB and more involved as well in adopting such technology. As discussed earlier in this study, people with a good level of education are more likely to have the sufficient knowledge and skills that could help them to cope with new technology rather than less educated people. Theoretically, this proposition has been highly supported by different studies conducted in the same area of interest $[2,28,38]$.

Respondents were also observed to be different in their intention and adoption of MB according to the variation in their income level. While the higher income respondents seem to be more interested and active users of MB services, lower income respondents are less interested and motivated in this regard. Over the marketing literature, it has been highly argued that the higher income customers are 
less sensitive for the cost issues $[25,36]$. Those customers are more able to carry the financial cost associated with buying the important facilities and resources required to use Mobile banking [20].

As it is expected, customer perceptions toward both behavioural intention and adoption are more likely to be different according to the customers' experience with technology and Internet. Indeed, the results regarding the willingness to adopt $\mathrm{MB}$ and the actual adoption of $\mathrm{MB}$ were able to reach the highest level among respondents who have a good level of technology experience for more than three years. As discussed in Section 3.5, the MB channel as self-service technology requires customers to independently conduct all the process to produce and transport the MB services. Therefore, adequate level of experience with technology is a very important aspect to let the customers be more confident in their ability to deal with such complicated systems. These results are consistent with other IS studies, which assured the important role of customers' experience in formulating the customers' perception and reaction to cope with different kinds of systems [10].

This study comprises an important contribution by exploring the main demographic features of adopters and potential adopters of Mobile banking in Jordan as more emerging system calling for further explanation and examination. Primarily, a theoretical contribution was captured in the current study by synthesising the relevant literature of IS area and Mobile banking as well. Further, such theoretical propositions were empirically tested via collecting sufficient amount of data from the Jordanian banking customers. Practically, the results of the current study alert the Jordanian banks about the current state of the Jordanian customers' intention and adoption of MB services. Therefore, by conducting an empirical study to discover the demographic features of adopters and potential adopters of $\mathrm{MB}$, this study was hoping to provide the Jordanian banks with relevant guidelines that would facilitate an effective implementation and acceptance of MB in proportion to the customer's category and their demographic characteristics. The main results of mean and standard deviation of behavioural intention obviously suggest that the majority of the respondents seem to be more motivated to adopt MB. In addition to this, most of them enjoy an adequate level of education and experience with the Internet and the computer, thus; moving them as actual users of MB will not be expensive and difficult. Therefore, allowing customers to try using these applications through experimental accounts rather than using their own accounts could create a positive experience and let customers actually experience how much they will benefit by using these valuable, useful and easier applications [13].

\section{Conclusion}

The fundamental intention of the current research was to discover how the Jordanian banking customers' perceptions on aspects related to their intention and adoption of MB could be differing because of their demographic features. Five common demographic variables, namely age, gender, income, education, and technology experience were identified and tested in the current study. The empirical findings 
clearly suggest that Jordanian banking customers are more likely to be different in their perceptions toward intention and adoption of $\mathrm{MB}$ according to their demographic differences.

\subsection{Limitations and Future Research Directions}

One of the main limitations of the current study is that the data was derived using a convenience sample of banking customers from two cities in Jordan: Amman and AlBalqa, raising a concern regarding the applicability of the current study results for other banking customers in different regions. Accordingly, it would be more useful for future studies to capture the required data from a large sample size covering the most parts in Jordan. This study only focuses on the customers' demographic features while it does not pay attention to the psychological and behavioral factors (such as habit, innovativeness, customer readiness, and self-efficacy). Therefore, examining such factors along with demographic features could provide a rich understanding of the customer's reaction and perception toward Mobile banking. Future studies should look at the impact of cultural aspects on the Jordanian customers' perceptions toward MB especially when such aspects have not been examined in the area of Mobile banking.

\section{References}

1. Al-Ashban, A.A., Burney, M.A.: Customer adoption of Telebanking technology: The case of Saudi Arabia. International Journal of Bank Marketing, 13(5), 191--201 (2001)

2. Al-Somali, S., Gholami, R., Clegg, B.: An investigation into the acceptance of online banking in Saudi Arabia. Journal of Business Research, 29(2), 130--141 (2009)

3. Alafeef, M., Singh, D., and Ahmad, K.: The Influence of Demographic Factors and User Interface on Mobile Banking Adoption: A Review. Journal of Applied Sciences, 12(20), 2082--2095 (2012)

4. Alalwan, A.A., Dwivedi, Y.K., Rana, N.P., Lal, B., and Williams, M.D.: Consumer adoption of Internet banking in Jordan: Examining the role of hedonic motivation, habit, self-efficacy and trust. Journal of Financial Services Marketing, 20(2), 145--157 (2015)

5. Awwad, M.S. and Ghadi, M.Y.: Investigating of factors influencing the intention to adopt mobile banking services in Jordan. Dirasat: Administrative Sciences, 37(2), 545-556 (2010)

6. Bhattacherjee, A.: Social science research: Principles, methods, and practices. (2nd Ed.). Florida, USA (2012)

7. Brown, I., Cajee, Z., Davies, D., and Stroebel, S.: Cell phone banking: predictors of adoption in South Africa - an exploratory study. International Journal of Information Management, 23(5), 381--394 (2003)

8. Burgess, R.: Key Variables in Social Investigation, Routledge, London (1986)

9. Chiu, Y., Fang, S., Tseng, C.: Early versus potential adopters: Exploring the antecedents of use intention in the context of retail service innovations. International Journal of Retail and Distribution Management, 38(6), 443--459 (2010)

10. Curran, J.M., Meuter, M.L., Surprenant, C.F.: Intentions to use self-service technologies: A confluence of multiple attitudes. Journal of Service Research, 5(3), 209--224 (2003)

11. Dabholkar, P.A., Bobbitt, M.L., Lee, E.J.: Understanding consumer motivation and behavior related to self-scanning in retailing: Implications for strategy and research on 
technology based self-service. International Journal of Service Industry Management, 14(1), 59--95 (2003)

12. Dean, D.H.: Shopper age and the use of self-service technologies. Managing Service Quality, 18(3), 225--238 (2008)

13. Dwivedi, Y.K., Irani, Z.: Understanding the adopters and non-adopters of broadband. Communications of the ACM, 52(1), 122--125 (2009)

14. Dwivedi, Y.K., Lal, B.: Socio-economic determinants of broadband adoption. Industrial Management \& Data Systems, 107(5), 654--671 (2007)

15. Dwivedi, Y.K., Choudrie, J., Brinkman, W.P.: Development of a survey instrument to examine consumer adoption of broadband. Industrial Management and Data Systems, 106(5), 700--718 (2006)

16. Dwivedi, Y.K., Wastell, D., Laumer, S., Henriksen, H.Z., Myers, M.D., Bunker, D., Elbanna, A., Ravishankar, M.N., Srivastava, S.C.: Research on information systems failures and successes: Status update and future directions. Information Systems Frontiers, 17(1), 143--157 (2015)

17. Finch, J.: "Age", in Burgess, R. (Ed.), Key Variables in Social Investigation, Routledge, London (1986)

18. Hanafizadeh, P., Behboudi, M., Koshksaray, A.A., Tabar, M.J.S.: Mobile-banking adoption by Iranian bank clients. Telematics and Informatics, 31(1), 62--78 (2014)

19. Khraim, H.S., Shoubaki, Y.E., Khraim, A.S.: Factors affecting Jordanian consumers' adoption of mobile banking services. International Journal of Business and Social Science, 2(20), 96--105 (2011)

20. Kolodinsky, J.M., Hogarth, J.M., Hilgert, M.A.: The adoption of electronic banking technologies by US consumers. The International Journal of Bank Marketing, 22(4), 238-$259(2004)$

21. Laukkanen, T.: Internet vs Mobile banking: comparing customer value perceptions. Business Process Management Journal, 13(6), 788--797 (2007)

22. Laukkanen, T., Pasanen, M.: Mobile banking innovators and early adopters: How they differ from other online users? Journal of Financial Services Marketing, 13(2), 86--94 (2008)

23. Luarn, P., Lin, H.H.: Toward an understanding of the behavioral intention to use Mobile banking. Computers in Human Behavior, 21(6), 873--891 (2005)

24. Mallat, N., Rossi, M., Tuunainen, V.: An empirical investigation of Mobile ticketing service adoption in public transportation. Pers Ubiquit Comput, 12(1), 57--65 (2008)

25. Meuter, M.L., Bitner, M.J., Ostrom, A.L., Brown, S.W.: Choosing among alternative service delivery modes: An investigation of customer trial of self-service technologies. Journal of Marketing, 69(2), 61--83 (2005)

26. Migdadi, Y.K.A.: The developing economies' banks branches operational strategy in the era of e-banking: The case of Jordan. Journal of Emerging Technologies in Web Intelligence, 4(2), 189--197 (2012)

27. Morgan, D.H.J.: "Gender", In Burgess, R. (Ed.), Key Variables in Social Investigation, Routledge, London (1986)

28. Proença, J., Rodrigues, M.A.: A comparison of users and non-users of banking self-service technology in Portugal. Managing Service Quality, 21(2), 192--210 (2011)

29. Purwanegara, M., Apriningsih, A., Andika, F.: Snapshot on Indonesia regulations in Mobile Internet banking users' attitudes. Procedia-Social and Behavioral Sciences, 115, 147--155 (2014)

30. Püschel, J., Mazzon, J.A., Hernandez, J.M.C.: Mobile banking: Proposition of an integrated adoption intention framework. International Journal of Bank Marketing, 28(5), 389--409 (2010)

31. Rana, N.P., Dwivedi, Y.K., Williams, M.D.: A meta-analysis of existing research on citizen adoption of e-government. Information Systems Frontiers, 17(3), 547--563 (2015a) 
32. Rana, N. P., Dwivedi, Y. K., Williams, M. D., Lal, B.: Examining the Success of the Online Public Grievance Redressal Systems: An Extension of the IS Success Model. Information Systems Management, 32(1), 39--59 (2015b)

33. Rana, N.P., Dwivedi, Y.K., Williams, M.D., Weerakkody, V.: Investigating success of an e-government initiative: Validation of an integrated IS success model. Information Systems Frontiers, 17(1), 127--142 (2015c)

34. Rana, N.P., Dwivedi, Y.K.: Citizen's adoption of an e-government system: Validating extended social cognitive theory (SCT). Government Information Quarterly, 32(2), 172-$181(2015)$

35. Riquelme, H.E., Rios, R.E.: The moderating effect of gender in the adoption of Mobile banking. International Journal of Bank Marketing, 28(5), 328--341 (2010)

36. Rogers, E.M.: Diffusion of Innovations, The Free Press, New York, NY (1995)

37. The Jordan Times.: Mobile phone penetration projected to reach $200 \%$. Available from: http://jordantimes.com/mobile-phone-penetration-projected-to-reach-200 on June 2, 2015 (2013)

38. Venkatesh, A., Shih, E., Stolzoff, N.: A longitudinal analysis of computing in the home. In Home Informatics and Telematics (pp. 205--215). Springer US. Chicago (2000)

39. Venkatesh, V., Morris, M.G.: Why don't men ever stop to ask for directions? Gender, social influence, and their role in technology acceptance and usage behaviour. MIS Quarterly, 24(1), 115--140 (2000)

40. Venkatesh, V., Morris, M., Davis, G., Davis, F.: User acceptance of information technology: Toward a unified view. MIS Quarterly, 27(3), 425--478 (2003)

41. Venkatesh, V., Thong, J.Y.L., Xu, X.: Consumer acceptance and use of information technology: Extending the unified theory of acceptance and use of technology. MIS Quarterly, 36(1), 157--178 (2012)

42. Wessels, L., Drennan, J.: An investigation of consumer acceptance of M-banking. International Journal of Bank Marketing, 28(7), 547--568 (2010)

43. Zhou, T.: Understanding users' initial trust in Mobile banking: An elaboration likelihood perspective. Computers in Human Behavior, 28(4), 1518--1525 (2012)

44. Zhou, T., Lu, Y., Wang, B.: Integrating TTF and UTAUT to explain Mobile banking user adoption. Computers in Human Behavior, 26(4), 760--767 (2010) 